\title{
The development of the organizational silence scale: Validity-reliability study ${ }^{1}$
}

\author{
Elif Daşc1 ${ }^{2}$ \\ Necati Cemaloğlu
}

\begin{abstract}
The aim of this study is to develop an Organizational Silence Scale based on primary school teachers' perceptions. The sample set of research were chosen from the population with the multistage sampling method. The first stage was stratified sampling and the second stage was simple random sampling. The sample of the study consisted of 15 schools and 414 teachers were have been working in primary schools of Ministry of National Education in 5 Central education districts of Aksaray, Turkey. For this purpose, an Organizational Silence Scale comprised of 38 items was developed. According to preliminary study on the scale, exploratory factor analysis was done. The KMO value was 0,98 and the Barlett`s Test of Sphericity reached statistical significance and 5 factors were obtained with the remained 36 items. Factor analysis of the scale revealed that the evaluation items cluster into 5 factors that account for $87,76 \%$ of the total variance. The explained variance of factors were $18,49 \% ; 18,49 \% ; 16,92 \% ; 16,38 \%$ and $15,30 \%$ respectively. According to the literature, these factors were named respectively as Individual, Administrative, Organizational Culture, Colleagues and Pressure Groups. In addition to test validity of the scale, first and second order confirmatory factor analysis were conducted. Also, Cronbach Alpha values ranged from 0,97 to 0,99 . Total Cronbach Alpha value was 0,95 and item total value was between 0,79 and 0,84 . The obtained values of the scale showed that scale is valid and reliable.
\end{abstract}

Keywords: Silence; organizational silence; teacher; validity; reliability.

\section{Introduction}

Deliberately being spared the ideas for improvement from the school's stakeholders in educational organizations affects the school's performance, development and quality of education negatively. The people who work in the organizational silence climate do not prefer to make any contribution to their organization (Bowen and Blackmon, 2003). So, organizational silence is seen as a potential threat in the context of organizational change and development (Çakıc1, 2008; Ellis and Dyne, 2009; Morrison and Milliken, 2000). Silence climate affects adversely the circulation of critical information and innovation in terms of organization (Huang, Van de Vliert and Van der Vegt, 2005; Özdemir and Sarığlu Uğur, 2013; Tangirala and Ramanujam, 2008). In the relevant literature, the conditions

\footnotetext{
1 This article was presented at the 1st International Conference on Lifelong Education and Leadership, in Olomouc, Czech on October 29-31, 2015.

${ }^{2}$ Research Assistant, Aksaray University, Institute of Social Sciences, elf2089@hotmail.com

${ }^{3}$ Professor Doctor, Gazi University, Faculty of Education, Department of Educational Administration, Supervision, Planning and Economy, necem@gazi.edu.tr
} 
Daşc1, E., \& Cemaloğlu, N. (2016). The development of the organizational silence scale: Validity-reliability study. International Journal of Human Sciences, 13(1), 32-45. doi:10.14687/ijhs.v13i1.3548

for the realization of silence in organizations are generally concentrated under individual, administrative, organizational culture and colleagues headings. However, pressure groups (unions and ethnic, religious and political pressure groups) also play an active role in the realization of organizational silence that quite a few place in the literature but intensely being felt in the implementation process.

The relevant literature shows that individual characteristics and preferences contribute to the silence situations (Kahveci, 2010; Kulınç, 2012; Kish-Gephart, Detert, Trevino and Edmondson, 2009; Kutlay, 2012; Premeaux and Bedeian, 2003; Ryan and Oestreich, 1991). Employees who have experienced organizational silence live fears as losing confidence in him/her, exclusion, shame/losing self-esteem (Bildik, 2009; Çakıc1, 2008; Ryan and Oestreich, 1991). Kılınç (2012) states that lack of confidence is one of the reasons to remain silent. This may be interpreted as a two-way interaction between organizational silence behavior and self-confidence. According to Kutlay (2012), as long as employees have more self-sufficiency level, their organizational silence levels decrease. Also, Premeaux and Bedeian (2003) state that reactive employees who believe that external forces control of his life prefer to remain silent rather than proactive employees.

From an administrative perspective, administrators who are decision and policy makers have a key role in remaining-silent (Alparslan, 2010; Batmunkh, 2011; Çakıc1, 2008; Erdoğan, 2011; Henriksen and Dayton, 2006; Kahveci and Demirtaş, 2013a; Kılınç, 2012; Park and Keil, 2009; Premeaux, 2001; Tangirala and Ramanujam, 2008; Vakola and Bouradas, 2005). According to Roberts and O'Reilly (1974), the administrators view determines communication behaviors exhibited by employees in the organization. Sarikaya (2013) states that as long as employees get involved in decision-making process in the organization, they feel themselves more valuable, their confidence in the organization increase and silence behavior decrease. In strict hierarchical organizations, administrators have top down communications with employees that is solely one-way (Blau and Scott, 1962). Morrison and Milliken (2000) proposed that the climate of silence is caused by organizational structures and policies. In addition, wall of silence can be destroyed in the organizations which have less power distance (Huang et al., 2005; Özdemir and Sarığlu Uğur, 2013).

Organizational culture has also a decisive role on silence (Bildik, 2009; Crockett, 2013; Çakı11, 2008; Kutlay, 2012; Scheufele and Moy, 2000; Shoemaker, Breen and Stamper, 2000). According to Bildik (2009), employees who live in the organizations that have a hard culture and objection to the top is a kind of disrespectful behavior can perceive this condition as normal. Silence can be perceived as a way of ensuring discipline and facilitating management by them. When providing more open and participatory organizational climate to employees, their organizational silence behaviors decrease (K1lınç, 2012, p. 93). The Abilene Paradox describes situations where people communicate agreement and do not take the time or make the effort to communicate their own ideas. Each person assumes that their own perspective is the only one that differs and so they express agreement with others (Harvey, 1988). This situation is referred to as one of the reasons employees' remain silent. According to Kllıçlar and Harbalıoğlu (2014), organizational silence can reduce employee motivation, job satisfaction and confidence in an organization. The reduction of feeling confidence reduces creativity and excitement with directing individuals to remain silent behavior (Afşar, 2013). The employees who exhibit silence behavior experience fear such as losing confidence in him, career opportunities and his job, exclusion and changing of duty station or unit (Bildik, 2009; Çakıc1, 2008; Kish-Gephart et al., 2009; Ryan and Oestreich, 1991).

When the organizational silence experienced status are examined, it draws attention among colleagues in the horizontal direction. Ryan and Oestreich (1991) state that the main reason to remain silent is the fear of any reaction. It was followed by the belief that speech is useless, avoiding conflict and 
Daşc1, E., \& Cemaloğlu, N. (2016). The development of the organizational silence scale: Validity-reliability study. International Journal of Human Sciences, 13(1), 32-45. doi:10.14687/ijhs.v13i1.3548

fear of stigmatization as troublemaker/complainer. It is an expected condition that employees prefer to remain silent where conflict with colleagues is perceived as a negative situation. According to Milliken, Morrison and Hewlin (2003), employees are able to remain silent not to lose selfesteem and confidence and to avoid exclusion in the organization. Also, mobbing behaviors such as envy, jealousy, competition, having come from a different culture and political reasons can lead to isolation and remain silent which took place between equivalents (Tinaz, 2011).

Pressure groups, which is considered one of the most important elements of democratic social structure, are focused to apply pressure to protect or realize their common interests. They want to have organization members to realize and protect the interests and force to make decisions in accordance with their wishes. Teacher unions in education sector are established to follow and contribute to the regulations as well as common professional interests of employees (Eraslan, 2012). According to the relevant literature, generally, there are divisions within the meaning of political views of teachers unions in Turkey (Aldatmaz, 2002; Baysal, 2006; Eraslan, 2013; Gül, 2007; Kayıkçı, 2013; Yasan, 2012; Yıldırım, 2007). Because of these differences, they can not show unity and provide support to each other in educational studies. Ethnic, religious and political ideologies are reflected in school through unions and the outweigh climate of critical environment is expected to occur in schools.

Although there are a good number of scales developed in relation to causes, results and issues of organizational silence in domestic (in Turkey) and international literature in the education and business field (Çakıcı and Çakı1, 2007; Çakı1, 2010; Van Dyne, Ang and Botero, 2003; Kahveci and Demirtaş, 2013b; Vakola and Bouradas, 2005), and not seen any scale which measures the level of realization of the organizational silence. The aim of this study is to develop an Organizational Silence Scale (OSS) based on primary school teachers' perceptions.

\subsection{Theoretical Framework}

Organizational silence is defined as the views and concerns related to organizational problems are not shared by the employees (Morrison and Milliken, 2000, p.707). Organizational silence has a significant impact on organizations, but there is not enough research on this issue in the literature (Bowen and Blackmon, 2003). According to Morrison and Milliken (2007), this concept is a collective phenomenon.

Current Turkish Dictionary defines silence as "not to be the noise around" ([Turkish Language Institution], 2015). According to Çakıcı (2007, p. 721) organizational silence is the intentionally act of employees to remain silent about the technical or behavioral issues which are related to employees' duties or workplace improvement.

Morrison and Milliken (2000, p. 721) say that if an employee feel a dangerous situation when he speak within the organization, he/she can deliberately choose to remain silent.

\section{Purpose}

This study aims to perform a validity-reliability tests by developing the Organizational Silence Scale based on primary school teachers' perceptions.

\section{Method}

This section contains information about the research design, population and sample, scale development process, data collection and analysis. 
Daşc1, E., \& Cemaloğlu, N. (2016). The development of the organizational silence scale: Validity-reliability study. International Journal of Human Sciences, 13(1), 32-45. doi:10.14687/ijhs.v13i1.3548

\subsection{Research Design}

Since this study has set out both to develop a new scale and to study its validity and reliability, it has been designed as a survey model.

\subsection{Population and Sample}

The population of the study consisted of teachers working in primary schools of Ministry of National Education in 5 Central education districts of Aksaray, Turkey during the 2014-2015 academic year. The sample set of research were chosen from the population with the multi-stage sampling method. The first stage was stratified sampling and the second stage was simple random sampling. 417 teachers from 15 schools filled out the surveys. 414 surveys were analyzed in the study.

Of the teachers included in the sample, 45,4 percent were women; 86 percent were married; ages ranged from 24 to 55; experience in their school ranged between 1 and 18 years; total experience ranged between 2 and 33; and 46,4 percent have been working in primary schools.

\subsection{Scale Development Process}

The most important step before developing any scale is to review the related literature. As such, both domestic and international literature in relation to organizational silence required review. Moreover, the theoretical basis related with this matter, similar research projects, data collecting tools, and the literature reviews used in these studies need to be compiled. These are: Afşar (2013), Alparslan (2010), Batmunkh (2011), Bayram (2010), Bildik (2009), Blau and Scott (1962), Botero and Dyne (2009), Bowen and Blackmon (2003), Brinsfield (2009), Brinsfield, Edwards and Greenberg (2009), Çakıc1 (2007; 2008; 2010), Çakıcı and Çakıcı (2007), Deming (1994), Detert and Edmondson (2005), Ellis and Dyne (2009), Erdoğan (2011), Erol (2012), Gül and Özcan (2011), Henriksen and Dayton (2006), Hirschman (1970), Huang et al. (2005), Kahveci (2010), Kahveci and Demirtaş (2013a; 2013b), Kılıçlar and Harbalıoğlu (2014), Kılınç (2012), Kish-Gephart et al. (2009), Kutlay (2012), Milliken et al. (2003), Morrison and Milliken (2000; 2003), Noelle-Neumann (1984), Oktay (2008), Özcan (2011), Özdemir and Sarığlu Uğur (2013), Park and Keil (2009), Premeaux (2001), Roberts and O’Reilly (1974), Ryan and Oestreich (1991), Sarrkaya (2013), Sarığlu (2011), Scheufele and Moy (2000), Shoemaker et al. (2000), Tangirala and Ramanujam (2008), Vakola and Bouradas (2005), Van Dyne et al. (2003).

During the second phase, the researchers prepared an item pool for the scale (38 items) in the form of 5-point Likert. The scale's anchor ranging from (1) strongly disagree to (5) strongly agree and higher numbers indicates increasing realization of the level of organizational silence. It was also examined by Turkish Language, Educational Administration and Assessment and Evaluation experts in terms of language and expression. After such evaluation, the scale began to be implemented to the sample group. Organizational Silence Scale was printed material form and requires paper-and-pencil application. A guideline was prepared for the assessment in which takes place such information as the purpose of the scale, the number of items in the scale, answering forms of matter, the estimated time, the identity of the person who prepared. Positive and negative items were distributed randomly into the trial scale.

\subsection{Data Collection and Analysis}

417 teachers filled out the surveys. However, the 3 survey was removed during the preliminary data screening procedure and 414 surveys were analyzed in the study. 
Exploratory Factor Analysis (EFA) was conducted in order to determine the scale factor structure with the obtained data. It was performed by using SPSS 18.0 software package. Then, reconstruction of the scale was performed. First and second order Confirmatory Factor Analysis (CFA) were conducted in order to verify the scale factor structure. It was also performed by using LISREL 8.80 software package.

When it comes to reliability analysis, Cronbach alpha reliability coefficient, item-total correlation coefficient, item discrimination index were figured out.

Thus, the development of Organizational Silence Scale was completed.

\section{Findings}

\subsection{Exploratory Factor Analysis Findings}

Data were analyzed and resolved using the SPSS 18.0 package program. Accordingly, the KaiserMayer-Olkin (KMO) value, Barlett's test, and exploratory factor analysis were figured out for validity analysis. The $\mathrm{KMO}$ value was 0,98 , exceeding the recommended value of 0,60 and the Barlett`s Test of Sphericity reached statistical significance $(p=0,00)$ (Büyüköztürk, 2012).

An exploratory factor analysis with varimax rotation was carried out to determine the construct validity. As a result of these analyses, 5 factors of the scale were calculated. Items below 0,30 factor load are removed from the scale. According to Büyüköztürk (2012), factor load can be drop down to 0,30 and difference between the maximum load value and the second highest one must be at least 0,10. Factor load value differences were examined and two items were removed from the scale (Item 7: I would be concerned with talk about problems at school and Item 13: Our principal, is reluctant to take ideas of teachers).

With the remaining 36 items were continued to the analysis of the scale and the results showed that repeated rotation regrouped under 5 factors.

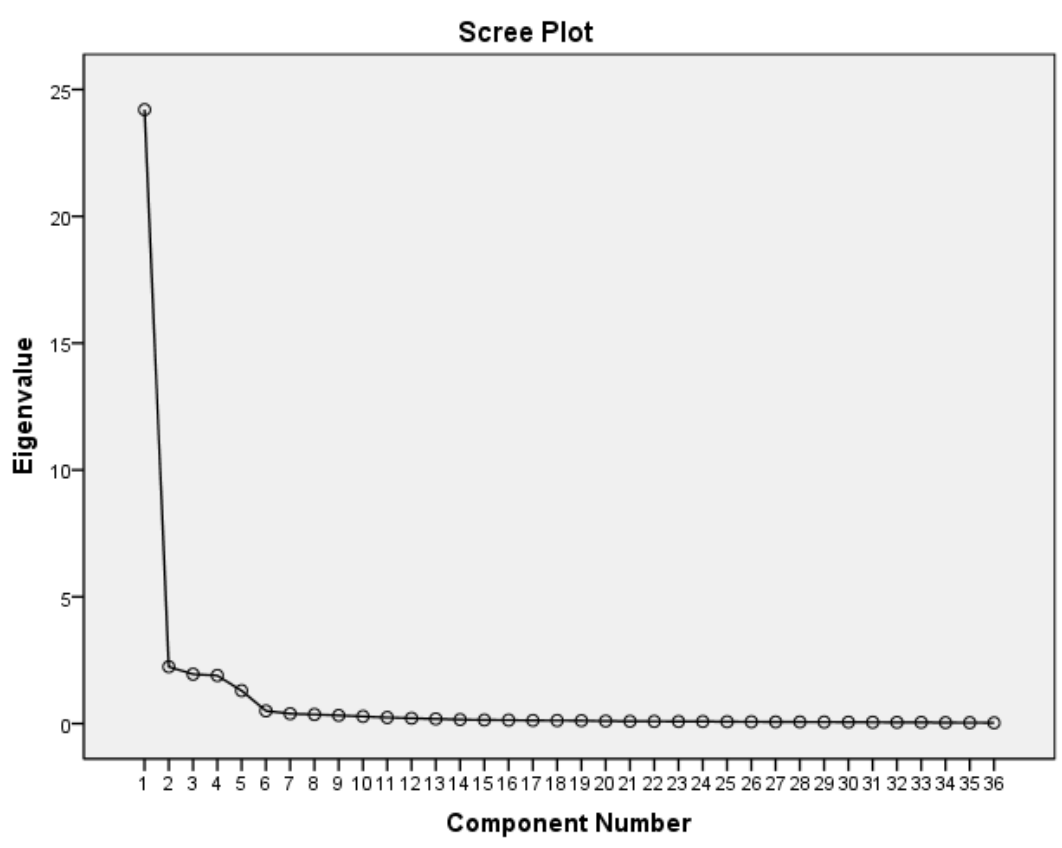

Figure 1. Scree Plot 
Daşc1, E., \& Cemaloğlu, N. (2016). The development of the organizational silence scale: Validity-reliability study. International Journal of Human Sciences, 13(1), 32-45. doi:10.14687/ijhs.v13i1.3548

Table 1. Factor Structure of Organizational Silence Scale

\begin{tabular}{llllll}
\hline \multirow{2}{*}{ Items } & \multicolumn{5}{l}{ Factor Load Values } \\
\cline { 2 - 5 } & F1 & F2 & F3 & F4 & F5 \\
\hline
\end{tabular}

1. Factor: Colleagues

29. We do not try to find solutions to problems in our school with my colleagues.

28. My colleagues do not like to talk about problems at school.

32. I cannot explain my ideas in social media (facebook and twitter) thinking of my sharings will be used against me in the future.

0,815

31. I cannot comment on the behavior of my colleagues that I disapprove.

30. When we face with a problem at school, we do exchange ideas with colleagues to solve.

26. I do not talk with my colleagues on disruptive issues.

27. If I share any problem in school with my colleagues, I could be excluded.

25. If I have a different opinion from my colleagues, I prefer not to say my mind.

\section{Factor: Individual}

5. I have an introverted personality that prevents me to interfere with the issues.

8. Although my views will contribute to the development of our school, I prefer not to say.

6. I am the one who can communicate easily with anyone about the problems in the school.

9. I isolate myself from the school environment.

0,772

2. I ignore some problems at school to protect myself.

1. I refrain from express problems in school.

4. I do not want to be heard bad information/news from me.

3. If I think about the solution of problems even different, I adapt to opinion of the majority.

\section{Factor: Organizational Culture}

24. The school environment is untrustworthy.

22. If I share any problem in school, I could be excluded.

23. When I talk about the problems in the school, my workload increases.

19. My idea is not asked about decisions in school.

20. I believe that speech is useless that changes nothing.

18. My idea is not taken for the solution of problems in school.

21. When I talk about the problems in the school, trust and respect decreases.

17. Not worth the effort to talk about problems in the school.

\section{Factor: Administrative}

14. I see it as disrespectful to appeal against a decision taken by our principal.

\section{Factor: Pressure Groups}

38. I cannot explain my ideas because of fear of losing my achievements. 
Daşc1, E., \& Cemaloğlu, N. (2016). The development of the organizational silence scale: Validity-reliability study. International Journal of Human Sciences, 13(1), 32-45. doi:10.14687/ijhs.v13i1.3548

37. Ethnic, religious and political pressures prevent me to explain my ideas.

34. It is affect my ideas that I was member of which union.

35. Political party groups stop me from telling my ideas clearly in school.

33. When I talk about problems at school, I feel the pressure of unions on me.

As a result of these analyses, factor load values were found to range between 0,583 and 0,823. When it comes to total variant value of the scale, it accounts for $87.76 \%$ and the explained variance of factors were $18,49 \%, 18,49 \%, 16,92 \%, 16,38 \%$ and $15,30 \%$ respectively. These results confirm that the scale had structure validity.

\subsection{Confirmatory Factor Analysis Findings}

Confirmatory factor analyses in LISREL 8.80 were conducted to investigate the factor structure and item performance of the offered 5 factors model of the OSS that separated as Individual, Administrative, Organizational Culture, Colleagues and Pressure Groups subscales. According to Muthen and Muthen (2002), a sample size of 150 is needed for the simplest CFA model with normally distributed continuous factor indicators and no missing data. It shows that 414 sample size of this study is enough for analysis. Then, the results of the LISREL program will suggest a critical evaluation of the adequacy of the study sampling, Critical $\mathrm{N}$ value will be further evaluated. After the tests of normality, it has been found that data sets have non-normality $(p<0,05)$. So, the analysis was done by using the Asymptotic covariance matrix (Şimşek, 2007) and Unweighted Least Squares Method (Kline, 2011).

Table 2. First Order CFA Findings of Organizational Silence Scale

\begin{tabular}{cccc}
\hline Factors / Items & t-values & Standardized Solutions & $R^{2}$ \\
\hline Individual & & & 0,83 \\
OSS1 & 32,42 & 0,91 & 0,88 \\
OSS2 & 36,45 & 0,94 & 0,67 \\
OSS3 & 22,58 & 0,82 & 0,72 \\
OSS4 & 25,36 & 0,85 & 0,85 \\
OSS5 & 29,97 & 0,92 & 0,85 \\
OSS6 & 32,57 & 0,92 & 0,83 \\
OSS8 & 30,30 & 0,91 & 0,88 \\
OSS9 & 32,59 & 0,94 & 0,88 \\
Administrative & & & 0,89 \\
OSS10 & 31,08 & 0,94 & 0,86 \\
OSS11 & 33,84 & 0,95 & 0,90 \\
OSS12 & 31,00 & 0,92 & 0,91 \\
OSS14 & 32,90 & 0,95 & 0,93 \\
OSS15 & 33,61 & 0,96 & 0,67 \\
OSS16 & 36,06 & 0,97 & 0,81 \\
Organizational Culture & & 0,73 \\
OSS17 & & 0,82 & 0,69 \\
OSS18 & 20,75 & 0,90 & 0,74 \\
OSS19 & 27,65 & 0,85 & 0,79 \\
OSS20 & 23,48 & 0,83 & 0,78 \\
OSS21 & 22,72 & 0,86 & \\
OSS22 & 24,39 & 0,89 & 0,89 \\
OSS23 & 26,31 & 0,88 & \\
OSS24 & 27,09 & & \\
Colleagues & 26,26 & & \\
\hline
\end{tabular}


Daşc1, E., \& Cemaloğlu, N. (2016). The development of the organizational silence scale: Validity-reliability study. International Journal of Human Sciences, 13(1), 32-45. doi:10.14687/ijhs.v13i1.3548

\begin{tabular}{llll}
\hline OSS25 & 37,52 & 0,95 & 0,91 \\
OSS26 & 39,70 & 0,96 & 0,93 \\
OSS27 & 40,75 & 0,96 & 0,93 \\
OSS28 & 39,69 & 0,96 & 0,93 \\
OSS29 & 38,16 & 0,96 & 0,92 \\
OSS30 & 39,56 & 0,97 & 0,93 \\
OSS31 & 39,12 & 0,97 & 0,93 \\
OSS32 & 39,39 & 0,97 & 0,93 \\
Pressure Groups & & \\
OSS33 & 29,32 & 0,94 & 0,87 \\
OSS34 & 29,71 & 0,93 & 0,86 \\
OSS35 & 29,25 & 0,92 & 0,85 \\
OSS36 & 31,82 & 0,91 \\
OSS37 & 33,24 & 0,95 & 0,94 \\
OSS38 & 30,96 & 0,97 & 0,89 \\
\hline
\end{tabular}

As shown in Table 2, t-values were significant regarding the explanation of the observed variables on the latent variables ( $t>2,56, \mathrm{p}<0,01)$. According to Jöreskog and Sörbom (1993, p. 107), t-value is considered significant that is more than 1,96 with 0,05 error margin. When standardized solutions were examined, it seems to be a highly significant relationship between observed and latent variables $(r \geq 0,67, p<0,01)$. Also, the validity coefficients reveal that the scale was valid $(r>0,30)$.

Critical $\mathrm{N}$ value was calculated as 207,06 . This value indicates that used 414 sample unit was sufficient in this study.

Table 3. Summary of First Order CFA Fit Indices for Organizational Silence Scale

\begin{tabular}{lcccccccc}
\hline Model & $\chi^{2}$ & $\left(\chi^{2} / s d\right)^{*}$ & RMSE $A$ & SRMR & NNFI & CFI & GFI & AGFI \\
\hline OSS: First Order & 1335,74 & 2,29 & 0,06 & 0,03 & 0,99 & 0,99 & 1,00 & 1,00 \\
\hline
\end{tabular}

$*_{\mathrm{sd}}=584, p<0,01$

First order CFA statistical analyses demonstrated that consisting of 5 factors and 36 items values were acceptable and overall fit statistics supported the model.

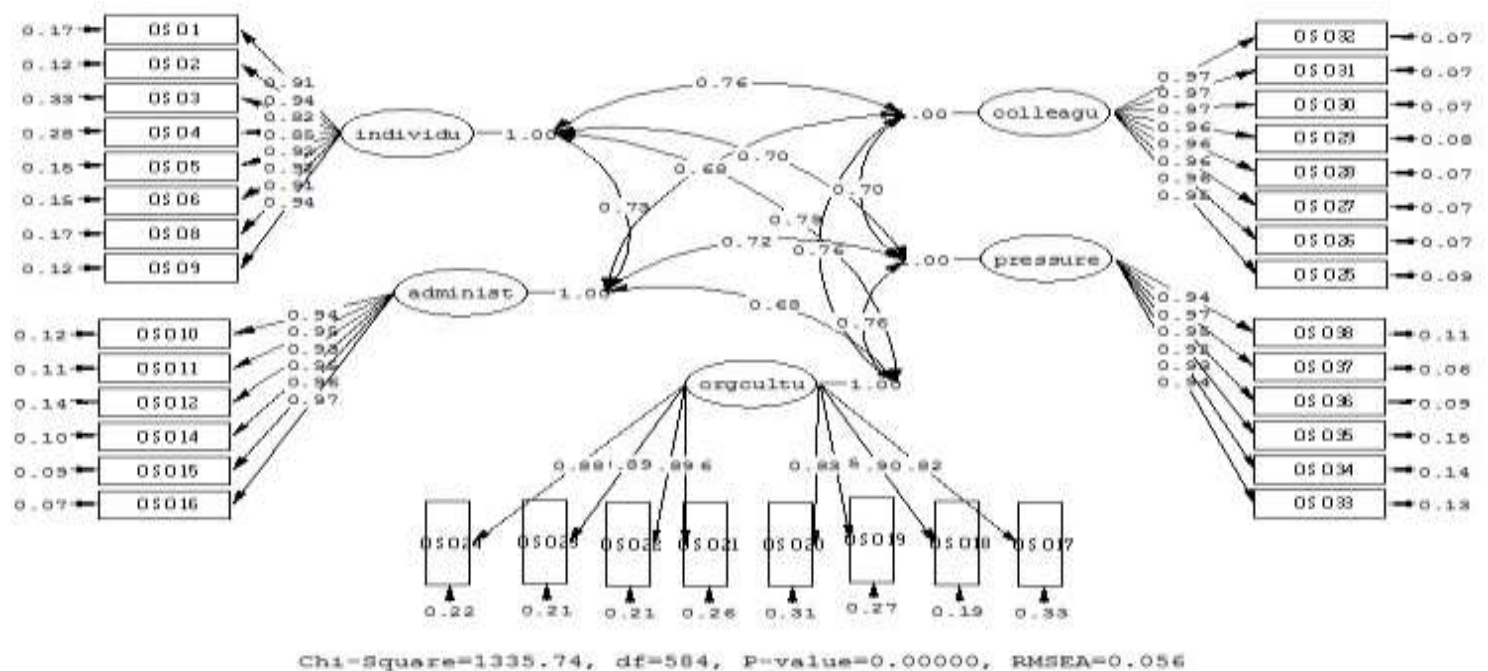

Figure 2. CFA findings: First order path diagram

Then, second order/higher order factor analysis was conducted to the scale. 
Daşc1, E., \& Cemaloğlu, N. (2016). The development of the organizational silence scale: Validity-reliability study. International Journal of Human Sciences, 13(1), 32-45. doi:10.14687/ijhs.v13i1.3548

Table 4. Second Order CFA Findings of Organizational Silence Scale

\begin{tabular}{|c|c|c|c|}
\hline Factors / Items & t-values & Standardized Solutions & $R^{2}$ \\
\hline \multicolumn{4}{|l|}{ Individual } \\
\hline OSS1 & & 0,91 & 0,83 \\
\hline OSS2 & 16,70 & 0,94 & 0,88 \\
\hline OSS3 & 14,47 & 0,82 & 0,67 \\
\hline OSS4 & 10,28 & 0,85 & 0,72 \\
\hline OSS5 & 5,83 & 0,92 & 0,85 \\
\hline OSS6 & 6,22 & 0,92 & 0,85 \\
\hline OSS8 & 7,00 & 0,91 & 0,83 \\
\hline OSS9 & 5,72 & 0,94 & 0,88 \\
\hline \multicolumn{4}{|l|}{ Administrative } \\
\hline OSS10 & & 0,94 & 0,88 \\
\hline OSS11 & 10,57 & 0,94 & 0,89 \\
\hline OsS12 & 10,75 & 0,93 & 0,86 \\
\hline OSS14 & 11,05 & 0,95 & 0,90 \\
\hline OSS15 & 10,78 & 0,96 & 0,91 \\
\hline OSS16 & 9,39 & 0,97 & 0,93 \\
\hline \multicolumn{4}{|c|}{ Organizational Silence } \\
\hline OSS17 & & 0,82 & 0,68 \\
\hline OSS18 & 4,21 & 0,90 & 0,81 \\
\hline OsS19 & 4,12 & 0,85 & 0,73 \\
\hline OSS20 & 3,50 & 0,83 & 0,69 \\
\hline OSS21 & 4,69 & 0,86 & 0,74 \\
\hline Oss22 & 3,14 & 0,89 & 0,79 \\
\hline OSS23 & 3,82 & 0,89 & 0,79 \\
\hline OSS24 & 4,62 & 0,88 & 0,78 \\
\hline \multicolumn{4}{|l|}{ Colleagues } \\
\hline OSS25 & & 0,95 & 0,91 \\
\hline Oss26 & 5,50 & 0,96 & 0,93 \\
\hline OSS27 & 5,48 & 0,96 & 0,93 \\
\hline OSS28 & 5,53 & 0,96 & 0,93 \\
\hline Oss29 & 5,56 & 0,96 & 0,92 \\
\hline OSS30 & 5,51 & 0,97 & 0,93 \\
\hline OsS31 & 5,54 & 0,97 & 0,93 \\
\hline OSS32 & 5,54 & 0,97 & 0,93 \\
\hline \multicolumn{4}{|c|}{ Pressure Groups } \\
\hline OSS33 & & 0,94 & 0,88 \\
\hline OSS34 & 11,30 & 0,93 & 0,86 \\
\hline OSS35 & 12,51 & 0,92 & 0,85 \\
\hline Oss36 & 7,17 & 0,95 & 0,91 \\
\hline OSS37 & 9,76 & 0,97 & 0,94 \\
\hline OSS38 & 11,83 & 0,94 & 0,89 \\
\hline
\end{tabular}

As shown in Table 4, $\mathrm{t}$-values are significant regarding the explanation of the observed variables on the latent variables $(t>2,56, \mathrm{p}<0,01)$. When standardized solutions were examined, it seems to be a highly significant relationship between observed and latent variables $(r>0,60, p<0,01)$. Also, the validity coefficients reveal that the scale was valid $(r>0,30, \mathrm{p}<0,01)$.

Critical $\mathrm{N}$ value was calculated as 204,13. This value indicates that used 414 sample unit was sufficient in this study. 
Daşc1, E., \& Cemaloğlu, N. (2016). The development of the organizational silence scale: Validity-reliability study. International Journal of Human Sciences, 13(1), 32-45. doi:10.14687/ijhs.v13i1.3548

Table 5. Summary of Second Order CFA Fit Indices for Organizational Silence Scale

\begin{tabular}{lcccccccc}
\hline Model & $\chi^{2}$ & $\left(\chi^{2} / s d\right)^{*}$ & RMSEA & SRMR & NNFI & CFI & GFI & AGFI \\
\hline OSS: Second Order & 1365,82 & 2,32 & 0,06 & 0,03 & 0,99 & 0,99 & 1,00 & 1,00 \\
\hline
\end{tabular}

$*_{\text {sd }}=589, p<0,01$

Second order CFA statistical analyses demonstrate that consisting of 5 factors and 36 items values were acceptable and overall fit statistics supported the model.

According to second order CFA results, all the factors of constituting the scale had a significant and positive impact on organizational silence. Individual and Organizational Culture factors affected organizational silence at the highest level $(\mathrm{r}=0,88 ; \mathrm{p}<0,01)$. These were followed respectively by Colleagues ( $\mathrm{r}=0,85 ; \mathrm{p}<0,01)$, Pressure Groups ( $\mathrm{r}=0,83 ; \mathrm{p}<0,01)$ and Administrative $(\mathrm{r}=0,81 ; \mathrm{p}<0,01)$ factors. It was also observed that all factors of the scale explain organizational silence in significant way. According to the data, the scale provided construct validity.

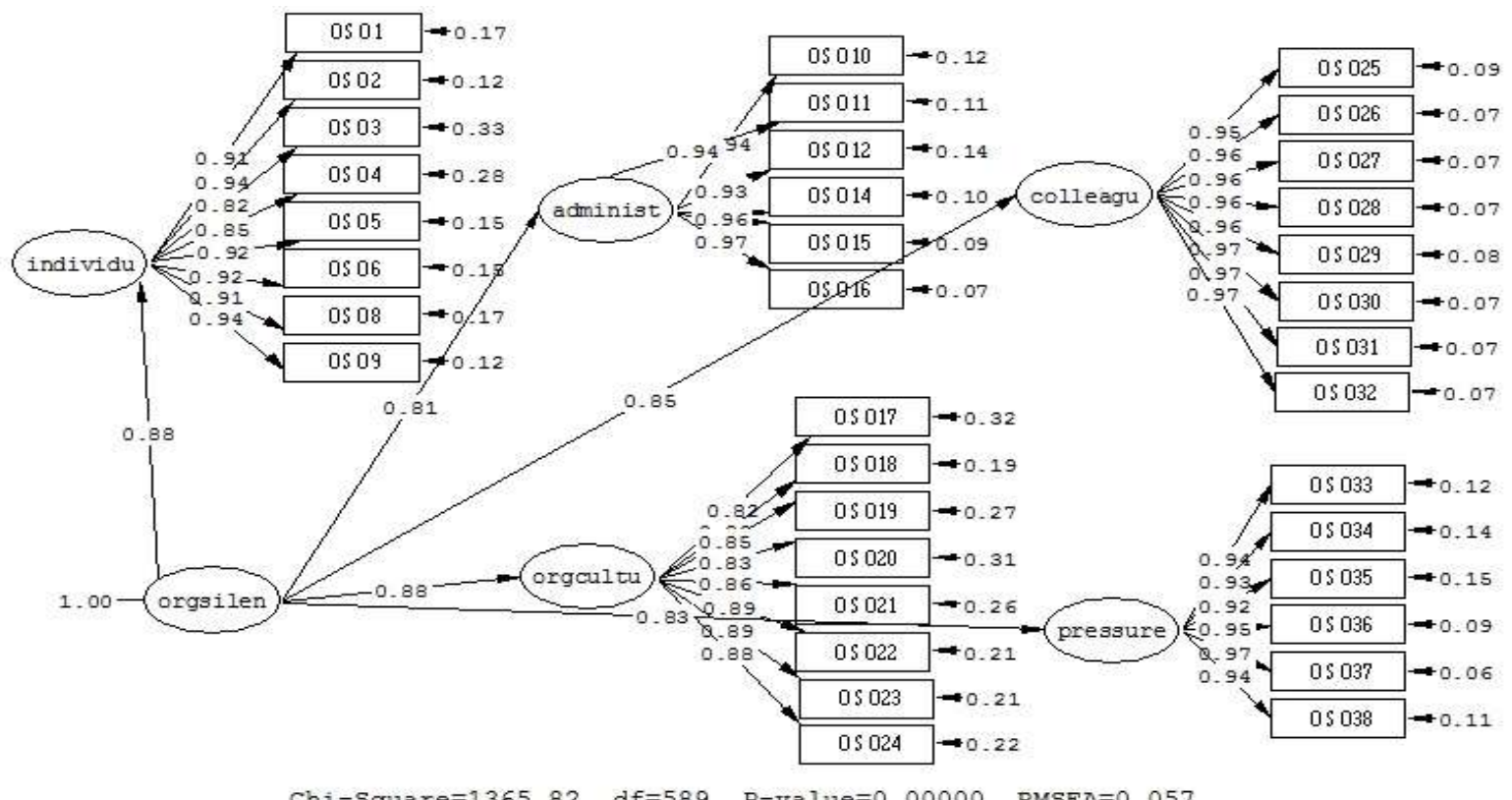

Figure 3. CFA findings: Second order path diagram

\subsection{Findings in relation to Reliability}

When it comes to reliability analysis, mean, standard deviation, Cronbach alpha reliability coefficient and relationships between factors were given in Table 6.

Table 6. Descriptive Statistics, a Coefficients (on the Diagonal), and Correlations of Variables

\begin{tabular}{lccccccc}
\hline Factor & $\bar{X}$ & $S$ & 1 & 2 & 3 & 4 & 5 \\
\hline 1.Individual & 3,09 & 1,09 & $(0,98)$ & & & & \\
2.Administrative & 3,11 & 1,17 & $0,71^{* *}$ & $(0,98)$ & & & \\
3.Organizational Culture & 3,01 & 0,95 & $0,76^{* *}$ & $0,66^{* *}$ & $(0,97)$ & & \\
4.Colleagues & 3,11 & 1,32 & $0,75^{* *}$ & $0,67^{* *}$ & $0,74^{* *}$ & $(0,99)$ & \\
5.Pressure Groups & 3,10 & 1,10 & $0,68^{* *}$ & $0,71^{* *}$ & $0,73^{* *}$ & $0,69 * *$ & $(0,98)$ \\
\hline Total & 3,08 & 0,99 & & & $(0,95)$ & & \\
\hline
\end{tabular}

$* * p<0,01 ;$ () Cronbach $\alpha$ values 
Daşc1, E., \& Cemaloğlu, N. (2016). The development of the organizational silence scale: Validity-reliability study. International Journal of Human Sciences, 13(1), 32-45. doi:10.14687/ijhs.v13i1.3548

Table 6 revealed that there was significant positive correlation between the factors constituting the OSS. Also, Cronbach Alpha values ranged from 0,97 to 0,99. Total Cronbach Alpha value of this scale accounted for 0,95 . In the case that the Cronbach alpha value is 0,70 or above, the scale is considered to be reliable (Büyüköztürk, 2012). Item total value was between 0,79 and 0,84. According to (Büyüköztürk, 2012), it can be stated that items of which item-total correlation is 0,30 and above distinct the individual very well. Overall, it became evident that the scale is effective and reliable.

\section{Conclusion and recommendations}

The findings of the study indicated that the OSS was an effective measurement tool. The scale consisted 36 items and it was formed as 5-point Likert. 5 factors have been obtained from the scale as a result of EFA. These factors were; Individual, Administrative, Organizational Culture, Colleagues and Pressure Groups. Also explained variance was figured out as \%87,76. EFA results show that the scale had validity at a good level.

In addition to test construct validity of OSS, first and second order CFA was conducted. First order results were; $\chi^{2} / s d$ value 2,29 (RMSE $A=0,06 ; S R M R=0,03 ; N N F I=0,99 ; C F I=0,99 ; G F I=1,00$; $A G F I=1,00)$; second order results were; $\chi^{2} /$ sd value 2,32 (RMSE $A=0,06 ; S R M R=0,03$; $N N F I=0,99 ; C F I=0,99 ; G F I=1,00 ; A G F I=1,00$. The obtained values of the scales show that scale was valid.

When it comes to reliability analysis, total Cronbach alpha value of this scale accounted for 0,95 . Also, Cronbach Alpha values of factors ranged from 0,97 to 0,99 . This results indicated that the scale had a high degree of reliability.

Consequently, all statistical analyses demonstrated that the scale is an effective scale. The obtained values of the scales show that scale is valid and reliable.

The scale that was developed in order to determine the level of experience of organizational silence of teachers can be adapted to school principals. In this case, the principals' silence experience levels can be determined. Additionally, the scale is applicable for teachers on students and other professional groups.

\section{References}

Afşar, L. (2013). Correlation of organizational silence and organizational trust: A research on the subject (Master's Thesis). İstanbul University, İstanbul.

Aldatmaz, E. (2002). Education unions in Turkey and the evulation of the activities (Master's Thesis). Gazi University, Ankara.

Alparslan, A. M. (2010). The interaction between organizational silence climate and employee silence behavior: A survey on instructors of Mehmet Akif Ersoy University (Master's Thesis). Süleyman Demirel University, Isparta.

Batmunkh, M. (2011). The relationship of leadership styles between organizational commitment and organizational silence and a research (Master's Thesis). Marmara University, İstanbul.

Bayram, T. Y. (2010). Organizational silence in universities (Master's Thesis). Abant Izzet Baysal University, Bolu.

Baysal, Ö. (2006). Elementary school teachers attitudes toward vocational organization (union): As a sample of Uşak province (Master's Thesis). Kocatepe University, Afyon. 
Daşc1, E., \& Cemaloğlu, N. (2016). The development of the organizational silence scale: Validity-reliability study. International Journal of Human Sciences, 13(1), 32-45. doi:10.14687/ijhs.v13i1.3548

Bildik, B. (2009). The relationship between the leadership styles, organizational silence and organizational commitment (Master's Thesis). Gebze High-Tech Institute, Gebze.

Blau, P. M., \& Scott, W. R. (1962). Formal organizations: A comparative approach. San Francisco: Chandler.

Botero, I. C., \& Dyne, L. V. (2009). Employee voice behavior: Interactive effects of LMX and power distance in the United States and Colombia. Management Communication Quarterly, 23(1), 84-104. doi:10.1177/0893318909335415

Bowen, F., \& Blackmon, K. (2003). Spirals of silence: The dynamic effects of diversity on organizational voice. Journal of Management Studies, 40(6), 1393-1417.

Brinsfield, C. T. (2009). Employee silence: Investigation of dimensionality, development of measures, and examination of related factors, dissertation (Doctoral dissertation). Ohio State University, Columbus, USA.

Brinsfield, C. T., Edwards, M. S., \& Greenberg, J. (2009). Voice and silence in organizations: Historical review and current conceptualizations. In J. Greenberg, \& M. S. Edwards (Eds.), Voice and silence in organizations (pp. 3-37). UK: Emerald.

Büyüköztürk, S.. (2012). Data analysis handbook for the social sciences. Statistics, research design, SPSS and comments. Ankara: Pegem A.

Cemaloğlu, N. (2012). Psychological aspects of school. S. Özdemir (Ed.), In Turkish education system and school management (pp. 197-229). Ankara: PegemA.

Crockett, D. A. (2013). Teacher silence in South Carolina public schools (Doctoral dissertation). Available from ProQuest Dissertations and Thesis database. (UMI No. 3609143)

Çakıc1, A. (2007). Silence at organizations: Theoretical backgrounds of silence and its Dynamics. Journal of Cukurova University Institute of Social Sciences, 16(1), 145-162.

Çakıc1, A. (2008). A research on issues, causes and perceptional results of silence at organizations. Journal of Cukurova University Institute of Social Sciences, 17(1), 117-134.

Çakıc1, A. (2010). Employee silence in organizations, Why do we prefer to remain silent? Ankara: Detay.

Çakıc1, A., \& Çakıc1, A. C. (2007, November, 21-23). A research on the perceived consequences of silence in the hotel business. Çeşme National Tourism Symposium Proceedings, 481-489.

Çokluk, Ö., Şekercioğlu, G., \& Büyüköztürk, Ş. (2012). Multivariate statistics for the social sciences, SPSS and LISREL applications. Ankara: Pegem.

Deming, W. E. (1994). Out of the crisis: Quality, productivity and competitive position. USA: Cambridge University.

Detert, J. R., \& Edmondson, A. C. (2005). No exit, no voice: The bind of risky voice opportunities in organizations. Academy of Management Proceedings, 1, 1-6.

Ellis, J. B., \& Dyne, L. V. (2009). Voice and silence as observers' reactions to defensive voice: Prediction based on communication competence theory. In J. Greenberg, \& M. S. Edwards (Eds.), Voice and silence in organizations (pp. 37-61). Bingley: Emerald

Eraslan, L. (2012). Evaluation of today's teacher unionism. Education and Society in the 21st Century, 1(1), 59-72.

Eraslan, L. (2013). Perceptions of prospective teachers union. Unpublished Research Report, Ankara.

Erdoğan, E. (2011). The relationship between effective leadership, organizational silence and performance (Master's Thesis). Gebze High-Tech Institute, Gebze.

Erol, G. (2012). The relationship between leadership styles and organizational silence: A study on hotels (Master's Thesis). Balıkesir University, Balıkesir.

Gül, M. H. (2007). The existing education unions in Turkey, the viewpoints of these unions regarding the main problems of education, the evaluation of their activities and efficiencies and the points of view of the teachers concerning these onions (Master's Thesis). Yeditepe University, İstanbul. 
Daşc1, E., \& Cemaloğlu, N. (2016). The development of the organizational silence scale: Validity-reliability study. International Journal of Human Sciences, 13(1), 32-45. doi:10.14687/ijhs.v13i1.3548

Gül, H., \& Özcan, N. (2011). The relationshpis between mobbing and organizational silence: An empirical study in the special provincial administration of Karaman. Journal of Kahramanmaras Sütçü Imam University Economics and Administrative Sciences, 2, 107-134.

Harvey, J. B. (1988). The Abilene paradox: The management of agreement. Organizational Dynamics, 3(1), 63-80. doi:10.1016/0090-2616(74)90005-9

Henriksen, K., \& Dayton, E. (2006). Organizational silence and hidden threats to patient safety. HSR: Health Services Research, 41(4), 1539-1554. doi:10.1111/j.1475-6773.2006.00564.x

Hirschman, A. O. (1970). Exit, voice, and loyalty. Cambridge, MA: Harvard University Press.

Huang, X., Van de Vliert, E., \& Van der Vegt, G. (2005). Breaking the silence culture: Stimulation of participation and employee opinion withholding cross-nationally. Management and Organization Review, 1(3), 459-482.

Jöreskog, K.G., \& Sörbom, D. (1993). LISREL 8: Structural equation modeling with the SIMPLIS command language. Chicago: Scientific Software International.

Kahveci, G. (2010). The relationship between organizational silence and organizational commitment in primary schools (Master's Thesis). Firat University, Elazı̆̆.

Kahveci, G., \& Demirtaş, Z. (2013a). School administrator and teachers' perceptions of organizational silence. Education and Science, 38(167), 50-64.

Kahveci, G., \& Demirtaş, Z. (2013b). Development study of organizational silence scale for teachers. Electronic Journal of Social Sciences, 12(43), 167-182.

Kayıkçı, K. (2013). Unionization in the public and education sector in Turkey, and expectations of school administrators and teachers expectations from unions. Public Administration Institute for Turkey and Middle East, 46(1), 99-126.

Kilıçlar, A., \& Harbalıŏlu, M. (2014). Relationship between organizational silence and organizational citizenship behavior: A case study on five stars hotels in Antalya. Journal of Business Research, 6(1), 328-346.

Kulınç, E. (2012). Investigation of organizational citizenship behavior, organizational silence and employee performance at physicians and nurses, and the relationship among them (Master's Thesis). Cumhuriyet University, Sivas.

Kish-Gephart, J. J., Detert, J. R., Trevino, L. K., \& Edmondson, A. C. (2009). Silenced by fear: The nature, sources, and consequences of fear at work. Research in Organizational Bebavior, 29, 163-193.

Kline, R. B. (2011). Principles and practice of structural equation modeling. NY London: The Guilford Press.

Kutlay, Y. (2012). The effect of organizational devotion and self-sufficiency of research assistants on organizational silence (Master's Thesis). Süleyman Demirel University, Isparta.

Milliken, F. J., Morrison, E. W., \& Hewlin, P. F. (2003). An exploratory study of employee silence: Issues that employees don't communicate upward and why. Journal of Management Studies, 40(6), 1453-1476.

Morrison, E. W., \& Milliken, F. J. (2000). Organizational silence: A barrier to change and development in a pluralistic world. Academy of Management Review, 25(4), 706-725.

Morrison, E. W., \& Milliken, F. J. (2003). Guest editors' introduction: Speaking up, remaining silent: The dynamics of voice and silence in organizations. Journal of Management Studies, 40(6), 1353-1358.

Muthen, L. K., \& Muthen, B. O. (2002). How to use a Monte Carlo study to decide on sample size and determine power. Structural Equation Modeling: A Multidisciplinary Journal, 9(4), 599-620. doi:10.1207/S15328007SEM0904_8

Noelle-Neumann, E. (1974). The spiral of silence: A theory of public opinion. Journal of Communication, 24(2), 43-51. 
Daşc1, E., \& Cemaloğlu, N. (2016). The development of the organizational silence scale: Validity-reliability study. International Journal of Human Sciences, 13(1), 32-45. doi:10.14687/ijhs.v13i1.3548

Noelle-Neumann, E. (1984). The spiral of silence. Chicago: University of Chicago Press.

Oktay, H. (2008). The obstacles which comes from the principle causes the lack of communication between the priciples and the teachers working in primary schools (Master's Thesis). Yeditepe University, İstanbul.

Özcan, N. (2011). The effect of mobbing on organizational citizenship and organizational silence: A Practice in the Administration of Special province of Karaman (Master's Thesis). Karamanoğlu Mehmetbey University, Karaman.

Özdemir, L., \& Sarroğlu Uğur, S. (2013). the evaluation employees’ organizational voice and silence perceptions in terms of demographic characteristics: A study in public and private sector. Journal of Ataturk University Economics and Administrative Sciences, 27(1), 257-281.

Park, C. W., \& Keil, M. (2009). Organizational silence and whistle-blowing on IT projects: An integrated model. Decision Sciences, 40(4), 901-918.

Pinder, C. C., \& Harlos, K. P. (2001). Employee silence: Quiescence and acquiescence as responses to perceived injustice. Research in Personnel and Human Resources Management, 20, 331-369.

Premeaux, S. F. (2001). Breaking the silence: Toward an understanding of speaking up in the workplace (Doctoral dissertation). Available from ProQuest Dissertations and Thesis database. (UMI No. 3021449)

Premeaux, S. F., \& Bedeian, A. G. (2003). Breaking the silence: The moderating effects of selfmonitoring in predicting speaking up in the workplace. Journal of Management Studies, 40(6), 1537-1562.

Roberts, K. H., \& O'Reilly, C. A. (1974). Failures in upward communication in organizations: Three possible culprits. The Academy of Management Journal, 17(2), 205-215.

Ryan, K. D., \& Oestreich, D. K. (1991). Driving fear out of the workplace: How to overcome the invisible barriers to quality, productivity, and innovation. San Francisco: Jossey-Bass.

Sarıkaya, M. (2013). Decision making processes and organizational silence (Master's Thesis). Pamukkale University, Denizli.

Scheufele, D. A., \& Moy, P. (2000). Twenty-five years of the spiral of silence: A conceptual review and empirical outlook. International Journal of Public Opinion Research, 12(1), 3-28.

Shoemaker, P. J., Breen, M., \& Stamper, M. (2000). Fear of social isolation: Testing an assumption from the spiral of silence. Irish Communications Review, 8, 65-78.

Şimşek, Ö. F. (2007). Structural equation modeling, basic principles and LISREL applications. Ankara: Ekinoks.

Tangirala, S., \& Ramanujam, R. (2008). Employee silence on critical work issues: The cross level effects of procedural justice climate. Personnel Psychology, 61(1), 37-68.

Tavşancil, E. (2005). The measurement of attitudes and data analysis with SPSS. Ankara: Nobel.

Tinaz, P. (2011). Mobbing. İstanbul: Beta.

Turkish Language Institution Current Turkish Dictionary. Ankara. http://www.tdk.gov.tr $(02 / 09 / 2015)$

Vakola, M., \& Bouradas, D. (2005). Antecedents and consequences of organisational silence: An empirical investigation. Employee Relations, 27(5), 441-458. doi: 10.1108/01425450510611997

Van Dyne, L., Ang, S., \& Botero, I. C. (2003). Conceptualizing employee silence and employee voice as multidimensional constructs. Journal of Management Studies, 40(6), 1359-1392.

Yasan, T. (2012). an evaluation of primary school administrators and teachers' opinions about in educational unions to according various variables: Case of Malatya city. Ondokuz Mayzs University Faculty of Education Journal, 31(1), 271-293.

Yildırım, İ. S. (2007). The relationship between teachers' unions and politics in the process of unionisation in Turkey (Master's Thesis). Sakarya University, Sakarya. 